\title{
Paleodrainages mapping on the Northern Amapá State, Maritime Basin of the Amazon River Mouth
}

Santos, V.F., Instituto de Pesquisas Científicas Tecnológicas do Estado do Amapá/IEPA; Universidade Federal do Amapá/UNIFAP.

Jardim, K.A., Universidade Federal Fluminense/UFF; Instituto de Pesquisas Científicas Tecnológicas do Estado do Amapá/IEPA.

Silva, J.P.F., Universidade Federal do Rio Grande do Norte/UFRN;Instituto de Pesquisas Científicas Tecnológicas do Estado do Amapá/IEPA.

Vital, H., Universidade Federal do Rio Grande do Norte/UFRN.

Figueiredo Jr., A.G., Universidade Federal Fluminense/UFF.

Copyright 2021, SBGf - Sociedade Brasileira de Geofísica.

This paper was prepared for presentation during the $17^{\text {th }}$ International Congress of the Brazilian Geophysical Society held in Rio de Janeiro, Brazil, 8-11 November 2021.

Contents of this paper were reviewed by the Technical Committee of the $17^{\text {th }}$ International Congress of the Brazilian Geophysical Society and do not necessarily represent any position of

the SBGf, its officers or members. Electronic reproduction or storage of any part of this paper for commercial purposes without the written consent of the Brazilian Geophysical Society is prohibited.

\begin{abstract}
Paleodrainages are morphological registers associated with major changes in river systems. The deactivation these systems involves broad processes of environmental changes, such as climate change, tectonics, and base-level variation. Occurrences of paleodrainages have been mapped in the coastal plain and marine areas of the Amapá state through several studies using satellite images (radar and optical sensors) and seismic data. Recently, new efforts have been made to understand the connection of paleodrainage systems with the geological evolution of this coastal plain and its inner continental shelf. These initiatives allowed us to understand the paleogeographic characteristics of the region, its connection with Holocene evolution and recent geological processes. The objective of this work is to present the efforts for the recognition of paleodrainage systems in the north of the mouth of the Amazon River using remote sensing and seismic data. Remote sensing information was provided by radar images ( $\mathrm{X}$ and $\mathrm{P}$ bands), Digital Terrain Model and Digital Surface Model and Landsat images. Technics of digital processing images were used to highlight paleodrainage systems. The equipment used to collect data in shallow waters was the Sub Bottom Profiler 512i, at various frequencies. Seismic records were processed using SonarWiz 5.0, where the internal reflectors were determined in the sedimentary package. The results show new evidence of paleodrainagens and new connections of these paleodrainagens with the current landscape of the region. For the region of Cabo North, many palaeochannels are arranged on old drainage patterns, distinct from the current drainage system. From the Flexal river to the south of Cassiporé Cape, the paleodrainagens are arranged in the same direction of actual estuarine systems. The deactivation of paleodrainages maybe occurred due to probable neotectonic phenomena influencing the migration of principal river of the hydrographic basins. The geological conditioning and regional plus global climatological context in long-term processes can be contributed for theses deativation. The data from this study must be considered preliminary and new surveys are needed for a precise characterization of the connection with the regional morphostructure in the region.
\end{abstract}

